\title{
RESPON PERTUMBUHAN DAN PRODUKSI KACANG HIJAU (VIGNA RADIATA L.) TERHADAP PERLAKUAN PERBEDAAN NAUNGAN
}

\section{Dewa Oka Suparwata}

Program Studi Agribisnis, Fakultas IImu-IImu Pertanian, Universitas Muhammadiyah Gorontalo, Jl. Prof. Dr. Mansoer Pateda, Pentadio Timur, Gorontalo, Indonesia 96181, E-mail: suparwata_do@umgo.ac.id

\begin{abstract}
This research aimed to study the respond of the growth and production of green beans toward shade treatment. The research location is in Pentadio Timur, Telaga Biru Gorontalo, which was done for 3 months from Desember 2016 to Februari 2017. The research design is RAK or group randomized design, with four level of treatment, which is, $P_{0}=$ without shade, $P_{1}=1$ layer of paranet thickness treatment, $P_{2}=2$ layer of paranet thickness treatment, $P_{3}=3$ layer of paranet thickness treatment. These four treatments was repeated 3 times that obtains 12 trial plots. The data were analyzed through Anova with SAS data processing. The result of variant investigation analysis on $B N T(P<0.05)$ showed that different treatment of shade is significant to the parameters of number of leaves on the $8^{\text {th }}$ week, number of branch on the $6^{\text {th }}$ and $8^{\text {th }}$ week. Meanwhile parameters of plant height, number of pods, and number of seeds per pods are not significantly different.
\end{abstract}

Keywords: Growth, Production, Green Beans, Shades

\section{Abstrak}

Tujuan penelitian ini adalah untuk mengkaji respon pertumbuhan dan produksi kacang hijau terhadap perlakuan naungan. Lokasi penelitian di Desa Pentadio Timur, Kecamatan Telaga Biru Gorontalo, dilakukan selama 3 Bulan dari Desember 2016 sampai Februari 2017. Rancangan penelitian menggunakan Rancangan Acak Kelompok (RAK) dengan 4 taraf perlakuan, yaitu: $\left(\mathrm{P}_{0}=\right.$ tanpa pemberian naungan (kontrol), $\mathrm{P}_{1}=$ perlakuan ketebalan paranet 1 lapis, $\mathrm{P}_{2}=$ perlakuan ketebalan paranet 2 lapis, dan $\mathrm{P}_{3}=$ perlakuan ketebalan paranet 3 lapis). Terdapat 4 perlakuan dan diulang sebanyak 3 kali, sehingga diperoleh 12 petak percobaan. Analisis data dilakukan dengan Analisis of Varian (Anova), menggunakan pengolah data SAS (Struktur Analisis Sintetik). Hasil analisis sidik ragam pada BNT $(P<0.05)$, menunjukkan bahwa perlakuan naungan berbeda nyata terhadap parameter jumlah daun minggu ke 8 , jumlah cabang minggu ke 6 dan 8 . Sedangkan parameter tinggi tanaman, jumlah polong dan jumlah biji per polong tidak berbeda nyata.

Kata Kunci: Pertumbuhan, Produksi, Kacang Hijau, Naungan 


\section{PENDAHULUAN}

Saat ini kacang hijau menduduki posisi ketiga setelah kedelai dan kacang tanah (Yugi dan Harjoso, 2012). Secara agronomis dan ekonomis, tanaman kacang hijau memiliki kelebihan dibanding tanaman kacang-kacangan lainnya (Atman, 2007), yaitu berumur genjah (55 hingga 65 hari), toleran kekeringan, dan dapat ditanam pada daerah yang kurang subur (lahan-lahan suboptimal) (Trustinah et al., 2014). Pertumbuhan tanaman baik dengan penyinaran 10 jam per hari (Sumarji, 2013).

Gorontalo merupakan salah satu daerah yang potensial dalam pengembangan kacang hijau. Namun, sampai saat ini produksi dan luas panen kacang hijau 15 tahun terakhir (2002-2016) berfluktuatif dan cenderung mengalami penurunan (Tabel 1).

Tabel 1. Data luas penen dan produksi kacang hijau di Provinsi Gorontalo

\begin{tabular}{ccc}
\hline Tahun & $\begin{array}{c}\text { Luas Panen } \\
(\mathrm{Ha})\end{array}$ & $\begin{array}{c}\text { Produksi } \\
\text { (Ton) }\end{array}$ \\
\hline 2002 & 248 & 249 \\
2003 & 680 & 745 \\
2004 & 736 & 865 \\
2005 & 595 & 726 \\
2006 & 549 & 621 \\
2007 & 420 & 515 \\
2008 & 325 & 396 \\
2009 & 229 & 286 \\
2010 & 226 & 280 \\
2011 & 172 & 218 \\
2012 & 154 & 198 \\
2013 & 139 & 182 \\
2014 & 98 & 131 \\
2015 & 105 & 138 \\
2016 & 100 & $\ldots{ }^{*}$ \\
\hline
\end{tabular}

*) tidak ada data
Sumber: BPS Provinsi Gorontalo, 2010; 2015; 2017.

Dalam upaya meningkatkan keberhasilan usahatani kacang hijau diperlukan suatu pola pengembangan yang bisa diadopsi oleh masyarakat petani. Demi mencapai tujuan produksi yang tinggi tentunya pengembangan kacang hijau membutuhkan lahan pertanian yang cukup luas. Hal ini menjadi problem di masyarakat ketika ingin menanam terkendala oleh minimnya kepemilikan lahan, dengan sistem pertanaman monokultur kacang hijau. Salah satu pola yang dapat diterapkan ialah dengan memanfaatkan ruang kosong pada lahan di bawah tegakan tanaman tahunan (kehutanan, perkebunan, hortikultura tahunan, dan lainnya), seperti misalnya pemanfaatan lahan di bawah tegakan kelapa, kakao, kelapa sawit, sengon, jati dan lainnya. Syaiful et al., (2011), tujuannya untuk efisiensi dalam pemanfaatan waktu, ruang dan sumberdaya alam yang tersedia, sehingga produksi usahatani dan pendapatan petani dapat ditingkatkan.

Namun disisi lain juga memiliki kelemahan, seperti terjadinya kompetisi atau perebutan cahaya matahari yang akan diterima antara tanaman pokok dengan tanaman kacang hijau sehingga tegakan di bawahnya akan ternaungi. Menurut Sopandie dan Trikoesoemaningtyas (2011), 
kendala utama pada lahan semacam ini adalah rendahnya intensitas cahaya karena faktor naungan. Sucipto (2009), menambahkan bahwa kompetisi terjadi apabila dalam suatu populasi terdapat persaingan yang berpengaruh terhadap faktor pertumbuhan seperti cahaya matahari, air, nutrisi, $\mathrm{CO}_{2}$, dan gas lainnya.

Dalam budidaya tanaman pertanian, adanya naungan sangat mempengaruhi intensitas radiasi, sehingga selain berpengaruh langsung terhadap tanaman, juga berpengaruh tidak langsung melalui perubahan iklim mikro di sekitar tanaman (Reskynawati, 2014). Naungan akan menghalangi cahaya matahari yang akan diserap oleh tanaman. Akibat dari kurangannya pasokan cahaya yang masuk ke tubuh tanaman. Chairudin et al., (2015), hal ini berimplikasi terjadinya penurunan jumlah pasokan fotosintat ke bagian biji sehingga terjadi penurunan jumlah polong isi dan bobot biji kering tanaman.

Toleransi tanaman kacang hijau terhadap naungan dapat ditinjau dari kemampuan tanaman tersebut beradaptasi dengan kondisi lingkungan tempat tumbuhnya. Naungan yang diberikan dan diterima sangat menentukan respon kacang hijau terhadap pertumbuhan dan produksinya. Tanaman yang ternanungi memiliki ciri seperti: (1) tanaman tumbuh kurus dan tinggi,
(2) daun berwarna hijau pucat, (3) jumlah cabang relatif lebih sedikit dibandingkan tanaman normal, (4) jumlah bunga berkurang, diameter batang relatif kecil, dan lainnya. Dalam kondisi ini (Sundari et al., 2005), kacang hijau mempunyai peluang yang baik untuk dikembangkan pada kondisi intensitas cahaya rendah.

Berdasarkan beberapa hal di atas, maka tujuan penelitian ini untuk mengkaji respon pertumbuhan dan produksi kacang hijau terhadap perlakuan naungan. Hal ini memberikan berkontribusi kepada petani dalam melakukan budidaya kacang hijau dengan memanfaatkan lahan kosong di bawah tegakan tanaman pokok tanaman-tanaman tahunan.

\section{METODE PENELITIAN}

Waktu dan Tempat Penelitian

Penelitian ini dilakukan pada Bulan Desember 2016 sampai Bulan Februari 2017, lokasi penelitian di Desa Pentadio Timur, Kecamatan Telaga Biru, Kabupaten Gorontalo, Provinsi Gorontalo.

\section{Rancangan Penelitian}

Penelitian ini merupakan jenis penelitian eksperimen. Perlakuan naungan yang diujicobakan merupakan modifikasi naungan berbahan paranet. Bahan ini diaplikasikan berdasarkan perlakuan ketebalan paranet (naungan) yang akan diberikan pada kacang hijau. Rancangan 
penelitian

menggunakan

Rancangan Acak Kelompok (RAK) dengan 4 taraf perlakuan, yaitu:
a. $\mathrm{P}_{0}=$ tanpa pemberian naungan (kontrol)
b. $\mathrm{P}_{1}=$ perlakuan ketebalan paranet 1 lapis
c. $\mathrm{P}_{2}=$ perlakuan ketebalan paranet 2 lapis
d. $\mathrm{P}_{3}=$ perlakuan ketebalan paranet 3 lapis

Terdapat 4 perlakuan dengan masing-masing perlakuan diulang sebanyak 3 kali, sehingga diperoleh 12 petak percobaan. Luas tiap petak percobaan adalah $3 \mathrm{~m} \times 4.5 \mathrm{~m}$, dengan jarak tanam yang digunakan adalah $30 \mathrm{~cm} \times 30$ $\mathrm{cm}$.

\section{Parameter Pengamatan}

Parameter pengamatan dalam penelitian ini tediri dari: (1) parameter pada fase pertumbuhan meliputi: tinggi tanaman, jumlah daun, jumlah cabang, dan (2) parameter pada fase produksi meliputi: jumlah polong dan jumlah biji perpolong.

\section{Analisis Data}

Analisis data dilakukan dengan Analisis of Varian (Anova), menggunakan bantuan pengolah data SAS (Struktur Analisis Sintetik). Jika $\mathrm{F}$ hitung lebih besar dari $F$ tabel maka dilakukan uji lanjut BNT 5\%.

\section{HASIL DAN PEMBAHASAN}

Tanaman dapat

memberikan respons positif/negatif terhadap perubahan lingkungan tumbuh (Taufiq dan Sundari, 2012). Faktor cahaya matahari salah satunya, menjadi sangat penting untuk menunjang pertumbuhan dan perkembangan kacang hijau. Menurut Zuchri (2007), persaingan untuk memperoleh sinar matahari memiliki arti penting bagi keberlanjutan pertumbuhan tanaman. Namun, keunggulannya kacang hijau menurut Sundari et al., (2005), yang merupakan tanaman C3 yang mempunyai tingkat kejenuhan cahaya lebih rendah dibandingkan dengan tanaman C4. Dengan demikian tanaman ini masih toleran terhadap cahaya rendah.

Berikut ini diuraikan hasil penelitian tentang respon kacang hijau terhadap perbedaan perlakuan naungan, yang diukur dari: tinggi tanaman, jumlah daun, jumlah cabang, jumlah polong dan jumlah biji per polong. Secara lebih rinci hasil penelitian dijelaskan sebagai berikut:

\section{Tinggi Tanaman Kacang Hijau}

Pengukuran tinggi tanaman kacang hijau dilakukan dengan cara mengukur dari leher akar sampai titik tumbuh tertinggi (Nasution, 2015). Dalam penelitian ini, tinggi tanaman diukur dari minggu ke 2, 4, 6 dan 8. Rata-rata tinggi tanaman kacang hijau disajikan pada Tabel 2.

Tabel 2. Data rata-rata tinggi tanaman kacang hijau pada berbagai perlakuan naungan 


\begin{tabular}{ccccc}
\hline \multirow{2}{*}{ Perlakuan } & \multicolumn{4}{c}{ Tinggi Tanaman (cm) } \\
\cline { 2 - 5 } & \multicolumn{3}{c}{ Pengamatan Minggu ke } \\
\cline { 2 - 5 } & $\mathrm{II}$ & $\mathrm{IV}$ & $\mathrm{VI}$ & $\mathrm{VIII}$ \\
\hline $\mathrm{P}_{0}$ & 13.8 & 19.2 & 36.2 & 53.0 \\
$\mathrm{P}_{1}$ & 14.6 & 21.6 & 40.6 & 47.9 \\
$\mathrm{P}_{2}$ & 15.8 & 21.5 & 38.9 & 48.3 \\
$\mathrm{P}_{3}$ & 15.6 & 19.4 & 33.8 & 41.3 \\
\hline $\mathrm{KK} \%$ & 10.7 & 6.7 & 11.5 & 27.1 \\
\hline
\end{tabular}

Sumber: Data Hasil Penelitian Diolah, 2017

Angka yang diikuti oleh huruf yang sama pada kolom yang sama menunjukkan tidak berbeda nyata pada uji BNT 5\%

Hasil sidik ragam pada BNT $(P<0.05)$, menunjukan bahwa tinggi tanaman dari setiap perlakuan tidak menunjukkan perbedaan yang nyata. Hal ini seperti yang dilaporkan oleh Buntuang et al., (2014), bahwa perlakuan pemberian naungan plastik transparan tidak berpengaruh nyata pada tinggi tanaman.

Masing-masing rata-rata tinggi tanaman tertinggi dari minggu ke-2 yaitu terdapat pada perlakuan P2 $(15.8 \mathrm{~cm})$, minggu ke-4 pada perlakuan $\mathrm{P} 1(21.6 \mathrm{~cm})$, minggu ke-6 pada perlakuan P1 $(40.6 \mathrm{~cm})$, dan minggu ke-8 pada perlakuan PO (53.0 $\mathrm{cm}$ ) dibandingkan perlakuan yang lain. Hal ini mengindikasikan bahwa terdapat perbedaan pada setiap fase pertumbuhan kacang hijau dilihat dari parameter tinggi tanaman. Pada awal pertumbuhan sampai pada minggu ke-6 kacang hijau memiliki respon yang baik terhadap naungan sehingga dapat tumbuh dengan baik. Hal ini didukung oleh Reskynawati (2014), bahwa tanaman dengan mekanisme penghindaran naungan yang tumbuh pada kondisi lingkungan yang ternaungi akan meningkatkan pemanjangan batang dan tangkai serta mengurangi jumlah cabang. Hasil penelitian oleh Susanto dan Sundari (2011), melaporkan tinggi tanaman di lingkungan tanpa naungan berkisar antara 27.8-72.1 cm dengan rata-rata $50.2 \mathrm{~cm}$, sedangkan pada lingkungan ternaungi berkisar antara 29.6-86.2 cm dengan rata-rata 58.6 $\mathrm{cm}$. Selanjutnya Afandi et al., (2013), melaporkan tingkat naungan berpengaruh nyata terhadap tinggi tanaman dan jumlah cabang dimana tanaman tertinggi terdapat pada N3 (60 \%), jumlah cabang terbanyak terdapat pada NO (tanpa naungan). lqbal et al., (2013), melaporkan bahwa tinggi tanaman terbesar terdapat pada penaungan $60 \%$ (S3) dan terendah pada so (tanpa naungan) yang mana $S 3$ berbeda nyata dengan semua penaungan. Chairudin et al., (2015), juga mengatakan bahwa interaksi naungan dan varietas berpengaruh meningkatkan tinggi batang tanaman.

Selanjutnya, hasil penelitian (Tabel 1), umur tanaman memasuki 8 minggu setelah tanam, kacang hijau membutuhkan cahaya yang lebih banyak sehingga respon pertumbuhan tertinggi terdapat pada perlakuan PO. Dapat dilihat pada Tabel 1 bahwa semakin bertambah umur, tanaman kacang hijau semakin banyak membutuhkan cahaya matahari. Pada Fase awal pertumbuhan tanaman yang ternaungi akan tumbuh cepat dan bergerak mengikuti arah datangnya cahaya matahari, tetapi tumbuh batang tanaman relatif tidak kokoh. Menurut Afandi et al., (2013), hal ini dikarenakan cahaya merupakan faktor yang penting dalam pertumbuhan.

Jumlah Daun Kacang Hijau 
Peran dan fungsi daun sangat vital pada pertumbuhan tanaman yakni bertindak sebagai dapur atau tempat berlangsungnya proses fotosintesis tanaman. Tanaman kacang hijau pasti yang tumbuh memiliki perbedaan jumlah daun, ini tergantung kemampuan individu tanaman tersebut menyerap unsurunsur hara yang nantinya akan digunakan dalam pembentukan daun. Posisi tumbuh daun juga sangat menentukan kemampuan penyerapan cahaya matahari. Tanaman yang memiliki posisi daun vertikal akan lebih baik dalam menyerap cahaya matahari dibandingkan dengan posisi daun tumbuh horizontal. Polnaya dan Patty (2012), mengungkapkan cahaya tersebut akan direduksi energi setelah melewati lapisan-lapisan daun pada kanopi tanaman. Hasil penelitian ratarata jumlah daun kacang hijau disajikan pada Tabel 3.

Hasil penelitian (Tabel 3) pada minggu ke 2, 4 dan 6 tidak menunjukkan perbedaan yang nyata pada BNT $(P<0.05)$. Rata-rata jumlah daun terbanyak berturut-turut, minggu ke-2 pada perlakuan PO (6.7 helai), minggu ke-4 pada perlakuan PO dan P2 (14.1 helai), dan minggu ke-6 pada perlakuan P0 dan P1 (20.8 helai). Namun, pada minggu ke 8 bahwa perlakuan naungan menunjukkan perbedaan yang nyata pada BNT $(P<0.05)$. Perlakuan P0 (31.7 helai) memiliki jumlah yang lebih banyak dibandingkan dengan perlakuan $\mathrm{P} 1$

Tabel 3. Data rata-rata jumlah daun kacang hijau pada berbagai perlakuan naungan

\begin{tabular}{|c|c|c|c|c|}
\hline \multirow{3}{*}{$\begin{array}{c}\text { Perlakua } \\
\mathrm{n}\end{array}$} & \multicolumn{4}{|c|}{ Jumlah Daun (Helai) } \\
\hline & \multicolumn{4}{|c|}{ Pengamatan Minggu ke } \\
\hline & II & IV & $\mathrm{VI}$ & VIII \\
\hline
\end{tabular}

\begin{tabular}{ccccc}
\hline P0 & 6.7 & 14.1 & 20.8 & $31.7 \mathrm{a}$ \\
P1 & 6.1 & 13.1 & 20.8 & $26.2 \mathrm{~b}$ \\
P2 & 6.5 & 14.1 & 19.8 & $26.3 \mathrm{a}$ \\
& & & & $\mathrm{b}$ \\
P3 & 6.1 & 12.2 & 17.3 & $19.4 \mathrm{c}$ \\
\hline BNT & & & & 5.02 \\
$(5 \%)$ & & & & \\
\hline KK \% & 11.1 & 11.1 & 11.9 & 9.8 \\
\hline
\end{tabular}

Sumber: Data Hasil Penelitian Diolah, 2017

Angka yang diikuti oleh huruf yang sama pada kolom yang sama menunjukkan tidak berbeda nyata pada uji BNT 5\%

(26.2 helai), P2 (26.3 helai) dan P3 (19.4 helai). Tetapi perlakuan $\mathrm{P} 1$ tidak berbeda nyata dengan perlakuan $\mathrm{P} 2$. Sedangkan perlakuan P3 sangat berbeda nyata dengan perlakuan $\mathrm{PO}$. Hal ini mengindikasikan bahwa jumlah daun kacang hijau akan banyak bila tanaman tersebut tidak ternaungi, terlihat dari data hasil penelitian bahwa pada perlakuan PO menunjukkan jumlah daun yang terbanyak. Berbeda dengan hasil penelitian yang dilaporkan oleh Deselina (2014), mengatakan bahwa kerapatan naungan justru memberikan pengaruh nyata terhadap luas daun, hasil uji lanjut bahwa N1 menunjukkan luas daun yang paling tinggi (44.067 cm2). Reskynawati (2014), melaporkan bahwa jumlah daun tanaman kacang hijau terbanyak terdapat pada naungan $0 \%$ (tanpa naungan) mencapai rata-rata 11,70 per helai dengan intensitas cahaya berkisar antara 290,50 kal.cm-2.hari-1 350,50 kal.cm-2.hari-1, suhu udara berkisar antara 31,50 0C-33,80 0C , dan kelembaban udara berkisar $84,30 \%-88,10 \%$, semakin besar tingkat naungan maka jumlah daun semakin sedikit. 
Disamping itu, pada awal perkecambahan daun yang kurang akan menyebabkan rendahnya klorofil pada kacang hijau. Seperti dijelaskan oleh Haryanti dan Budihastuti (2015), bahwa intensitas cahaya rendah menyebabkan klorofil kurang terbentuk dalam kotiledon tersebut, adanya klorofil yang mulai terbentuk dan cukup baik akan berfungsi dalam menangkap cahaya pada proses fotosintesis. Zuchri (2007), berkurangnya radiasi yang diterima organ daun berdampak pada produk fotosintat. Rezkinawati (2014), pertumbuhan daun atau penambahan jumlah daun sangat menghendaki cahaya matahari. Seperti yang kita ketahui bahwa daun merupakan penerima cahaya matahari sebagai pembentukan cadangan makanan bagi tanaman untuk pertumbuhan tanaman itu sendiri.

Jumlah Cabang Kacang Hijau

Cabang tanaman merupakan tempat tumbuhnya daun. Apabila jumlah cabang kecil, maka jumlah daun juga menjadi kecil. Hal tersebut berkaitan langsung dengan luas daun seluruh tanaman (Afandi et al., 2013). Cabang dapat terbentuk karena tinggi tanaman tidak optimal, sehingga tanaman lebih cenderung memperbanyak cabang kesamping. Terbentuknya cabang yang banyak akan membentuk daun yang banyak pula. Pada penelitian ini, pengamatan jumlah cabang kacang hijau dilakukan pada minggu ke 6 dan minggu ke 8 , hal ini dikarenakan pada minggu ke 2 dan 4 tanaman belum menampakkan pertumbuhan cabangnya. Hasil analisis rata-rata jumlah cabang kacang hijau terhadap perlakuan naungan menunjukkan perbedaan yang nyata pada BNT $(P<0.05)$. Hasil penelitian rata-rata jumlah cabang kacang hijau disajikan pada Tabel 4.

Hasil penelitian (Tabel 4) menunjukkan bahwa perlakuan naungan berbeda nyata pada BNT $(P<0.05)$. Rata-rata jumlah cabang pada minggu ke 6 perlakuan P0 (4.4 cabang) berbeda nyata dengan perlakuan P2 (2 cabang) dan P3 (2.9 cabang), namun tidak berbeda nyata dengan P1 (4.4 cabang). Demikian halnya pada perlakuan P2 dan P3 tidak berbeda nyata tetapi berbeda nyata dengan perlakuan $\mathrm{P} 0$ dan $\mathrm{P} 1$. Selanjutnya rata-rata jumlah cabang pada minggu ke 8 menunjukkan perlakuan P1 (6.3 cabang) berbeda nyata dengan perlakuan P2 (2.2 cabang) dan P3 (2.9 cabang), namun tidak berbeda nyata dengan perlakuan P0 (5.9 cabang). Demikian halnya pada perlakuan P3 tidak berbeda dengan $\mathrm{P} 2$, namun berbeda nyata dengan perlakuan $\mathrm{P} 1$ dan $\mathrm{P} 0$.

Tabel 4. Data rata-rata jumlah cabang kacang hijau dengan berbagai perlakuan naungan

\begin{tabular}{ccc}
\hline \multirow{2}{*}{ Perlakuan } & \multicolumn{2}{c}{ Jumlah Cabang } \\
\cline { 2 - 3 } & \multicolumn{2}{c}{ Pengamatan Minggu Ke } \\
\cline { 2 - 3 } & VI & VIII \\
\hline P0 & $4.4 \mathrm{a}$ & $5.9 \mathrm{a}$ \\
P1 & $4.1 \mathrm{a}$ & $6.3 \mathrm{a}$ \\
P2 & $2 \mathrm{~b}$ & $2.2 \mathrm{~b}$ \\
P3 & $2.9 \mathrm{ab}$ & $2.9 \mathrm{~b}$ \\
\hline BNT $(5 \%)$ & 1.5 & 2.3 \\
\hline KK $(\%)$ & 21.9 & 26.4 \\
\hline
\end{tabular}

Sumber: Data Hasil Penelitian Diolah, 2017

Angka yang diikuti oleh huruf yang sama pada kolom yang sama menunjukkan tidak berbeda nyata pada uji BNT 5\%

Relevan dengan penelitian yang dilakukan oleh Afandi et al., (2013), bahwa rataan jumlah cabang 
tertinggi pada perlakuan naungan terdapat pada NO (6,50 cabang) berbeda nyata dengan $\mathrm{N} 1 \quad(4,73$ cabang), N2 (3,27 cabang), dan N3 (2,90 cabang), sedangkan rataan jumlah cabang terendah pada perlakuan naungan terdapat pada N3 (2,90 cabang) berbeda tidak nyata dengan N2 (3,27 cabang). Selanjutnya dilaporkan oleh Budiastuti (2000), bahwa pada jarak tanam renggang, penerimaan intensitas cahaya menjadi besar dan memberikan kesempatan pada tanaman untuk tumbuh kearah menyamping. Dengan demikian akan mempengaruhi banyak sedikitnya cabang yang terbentuk.

Jumlah Polong

Polong kacang hijau berbentuk bulat panjang dengan bulu-bulu pendek, panjang polong 6-15 cm dengan 6-16 biji per polong (Sumarji, 2013). Parameter pengamatan produksi kacang hijau dalam penelitian ini salah satunya diukur melalui jumlah polong per tanaman. Pengamatan jumlah polong dilakukan pada minggu ke 6 dan minggu ke 8 . Analisis data menunjukkan bahwa perlakuan berbagai naungan tidak berpengaruh nyata terhadap jumlah polong kacang hijau pada BNT $(P<0.05)$. Hasil rata-rata perlakuan naungan terhadap jumlah polong kacang hijau disajikan dalam Tabel 5.

Pada Tabel 5, hasil uji lanjut BNT $P<0.05$ menunjukkan bahwa tidak ada perbedaan yang nyata perlakuan naungan terhadap jumlah polong baik pada pengamatan minggu ke 6 dan 8. Rata-rata jumlah polong kacang hijau pada masing-masing pengamatan pada minggu ke-6 polong terbanyak
Tabel 5. Data rata-rata jumlah polong kacang hijau dengan berbagai perlakuan naungan

\begin{tabular}{ccc}
\hline \multirow{2}{*}{ Perlakuan } & \multicolumn{2}{c}{ Jumlah Polong } \\
\cline { 2 - 3 } & \multicolumn{2}{c}{$\begin{array}{c}\text { Pengamatan Minggu } \\
\text { Ke }\end{array}$} \\
\cline { 2 - 3 } & $\mathrm{VI}$ & $\mathrm{VIII}$ \\
\hline P0 & 4 & 7 \\
P1 & 6 & 10 \\
P2 & 3 & 3 \\
P3 & 1 & 4 \\
\hline KK (\%) & 73 & 66 \\
\hline
\end{tabular}

Sumber: Data Hasil Penelitian Diolah, 2017

Angka yang diikuti oleh huruf yang sama pada kolom yang sama menunjukkan tidak berbeda nyata pada uji BNT 5\%

terdapat pada perlakuan P1 (5.6 polong), selanjutnya disusul dengan P0, P2 dan P3. Selanjutnya rata-rata jumlah polong pada minggu ke-8 terbanyak terdapat pada perlakuan P1 (10.1 polong), selanjutnya disusul dengan $\mathrm{P} 0, \mathrm{P} 3$ dan P2. Hal ini mengindikasikan bahwa meskipun tidak berbeda nyata, namun perlakuan naungan dengan ketebalan paranet 1 lapis memberikan respon lebih baik terhadap perkembangan jumlah polong, baik pada pengamatan minggu ke 6 dan 8 . Dapat dikatakan bahwa pada saat pembentukan polong tanaman kacang hijau menghendaki keseimbangan suhu yang diterimanya. Karena apabila cahaya matahari yang diberikan pada saat pembentukkan polong berlebihan, maka transpirasi tanaman berlebih dan evaporasi tanah semakin meningkat sehingga pengisian polong tidak sempurna disebabkan oleh kurangnya cadangan air dan kelembaban tanah. Tetapi juga tidak terlalu menghendaki naungan yang berlebih. Sepadan 
dengan hasil penelitian yang dilakukan oleh Reskynawati (2014), tentang pengaruh tingkat naungan terhadap pertumbuhan dan produksi kacang hijau yang menyatakan bahwa rata-rata jumlah polong isi terbesar pada naungan 50\% mencapai 7.76 dengan intensitas cahaya berkisar

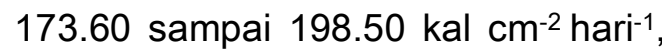
suhu udara berkisar antara 28.10 sampai $29.90{ }^{\circ} \mathrm{C}$ dan kelembaban udaranya berkisar antara 86.30 sampai $88.40 \%$. Perbedaan produksi yang diperoleh disebabkan karena adanya perbedaan tingkat naungan dan iklim mikro yaitu intensitas radiasi, suhu dan kelembaban. Afandi et al., (2013), melaporkan bahwa rataan jumlah polong berisi pertanaman tertinggi pada perlakuan naungan terdapat pada N0 (103.60 polong) berbeda tidak nyata dengan $\mathrm{N} 1$ (98.13 polong) sedangkan rataan jumlah polong berisi pertanaman terendah pada perlakuan naungan terdapat pada N3 (34.25 polong).

Jumlah Biji Per polong

$$
\text { Jumlah polong sangat }
$$

berhubungan dengan biji yang ada didalam polong tersebut (Sands, 1995 dalam Budiastuti, 2000). Semakin panjang polong kacang hijau maka semakin banyak biji yang terdapat dalam polong tersebut. Sumarji (2013), biji kacang hijau kecil dan bulat, berwarna hijau atau hijau kekuningan dengan bobot 100 bijinya antara 3-4 gram.

Dalam penelitian ini, pengamatan jumlah biji per polong dilakukan pada minggu ke 9, tepat pada saat panen pertama. Rata-rata hasil pengamatan jumlah biji per polong kacang hijau disajikan pada Tabel 6.
Pada Tabel 6, hasil uji lanjut BNT $P<0.05$ menunjukkan bahwa tidak ada perbedaan yang nyata perlakuan naungan terhadap jumlah biji per

Tabel 6. Data rata-rata jumlah biji per polong kacang hijau dengan berbagai perlakuan naungan

\begin{tabular}{cc}
\hline Perlakuan & Jumlah Biji Per Polong \\
\hline P0 & 13 \\
P1 & 14 \\
P2 & 12 \\
P3 & 11 \\
\hline KK (\%) & 11
\end{tabular}

Sumber: Data Hasil Penelitian Diolah, 2017

Angka yang diikuti oleh huruf yang sama pada kolom yang sama menunjukkan tidak berbeda nyata pada uji BNT 5\% polong kacang hijau. Rata-rata jumlah biji per polong kacang hijau terbanyak terdapat pada perlakuan P1 (14 biji/polong), kemudian P0 (13 biji/polong), P2 (12 biji/polong), dan terendah pada P3 (11 biji/polong). Hasil penelitian ini mengindikasikan bahwa penerimaan cahaya matahari akibat perlakuan naungan paranet satu lapis memberikan hasil tertinggi dibandingkan tanpa naungan dan naungan ketebalan 2 dan 3 lapis. Intensitas cahaya matahari yang seimbang menentukan pembentukan polong tanaman kacang hijau. Disamping itu juga pemberian perlakuan ketebalan naungan 1 lapis memberikan kondisi iklim mikro yang sesuai untuk pembentukan biji per polong kacang hijau, karena terjadinya keseimbangan pengaturan suhu dan kelembabannya. Berbeda dengan hasil penelitian yang dilaporkan oleh lqbal et al., (2013), bahwa perlakuan naungan terhadap jumlah biji per tanaman sampel saling 
berbeda nyata dimana paling banyak terdapat pada S0 dengan rataan 67.87 biji dan paling sedikit pada S3 dengan rataan 5.00 biji.

Penerimaan cahaya matahari sangat berdampak pada pembentukan polong dan biji per polong kacang hijau. Minimnya pembentukan polong diakibat rendahnya penerimaan cahaya berkorelasi pada rendahnya produksi kacang hijau. Pada penanaman kacang hijau di bawah tegakan tanaman tahunan menyebabkan yang tanaman ternaungi sehingga kompetisi cahaya matahari menjadi lebih kompleks. Hal ini dikatakan oleh Sundari et al., (2005), bahwa persaingan cahaya merupakan salah satu faktor penyebab tingginya penurunan hasil kacang hijau pada sistem tumpangsari, Daeli et al., (2013), dan masih rendahnya produktivitas hasil. Laporan penelitian oleh lqbal et al., (2013), bahwa pada perlakuan naungan berpengaruh nyata terhadap produksi per plot dimana tertinggi pada SO dengan rataan $50,21 \mathrm{~g}$ dan terendah pada $\mathrm{S} 2$ dengan rataan $28,47 \mathrm{~g}$.

\section{PENUTUP}

Kesimpulan

Hasil analisis sidik ragam pada BNT $(P<0.05)$, perlakuan naungan berbeda nyata terhadap:

parameter jumlah daun minggu ke 8 bahwa perlakuan PO memiliki jumlah yang lebih banyak (31.7 helai) dibandingkan dengan $\mathrm{P} 1$ (26.2 helai), P2 (26.3 helai) dan P3 (19.4 helai), (2) parameter jumlah cabang minggu ke 6 perlakuan PO (4.4 cabang) berbeda nyata dengan perlakuan P2 (2 cabang) dan P3 (2.9 cabang), namun tidak berbeda nyata dengan P1 (4.4 cabang), dan pada minggu ke 8 menunjukkan perlakuan P1 $\quad(6.3$ cabang) berbeda nyata dengan perlakuan P2 (2.2 cabang) dan P3 (2.9 cabang), namun tidak berbeda nyata dengan perlakuan PO (5.9 cabang). Sedangkan parameter tinggi tanaman, jumlah polong dan jumlah biji per polong tidak berbeda nyata.

\section{Saran}

Beberapa saran dapat direkomendasikan: (1) dalam penerapan dilapangan petani dapat memanfaatkan lahan-lahan yang ternaungi seperti lahan kosong di bawah tegakan tanaman tahunan, (2) perlu dimunculkan varietas kacang hijau yang toleran terhadap naungan, sehingga meskipun dalam kondisi ternaungi tanaman masih dapat berproduksi optimal, dan (3) perlu dilakukan kajian lebih lanjut terhadap respon pertumbuhan dan produksi kacang hijau dengan perlakuan naungan.

\section{DAFTAR PUSTAKA}

Afandi, M., Mawarni, L., dan Syukri. (2013). Respon Pertumbuhan dan Produksi Empat Varietas Kedelai (Glycine max L.) terhadap Tingkat Naungan. Jurnal Online Agroekoteknologi, 1(2): 214-226.

Atman. (2007). Teknologi Budidaya Kacang Hijau (Vigna radiata L.) di Lahan Sawah. Jurnal IImiah Tambua, 6(1): 89-95.

Badan Pusat Statistik (BPS) Provinsi Gorontalo. (2010). Provinsi Gorontalo dalam Angka: Gorontalo.

(2015). Provinsi Gorontalo dalam Angka: Gorontalo. 
.(2017). Provinsi Gorontalo dalam Angka: Gorontalo.

Budiastuti, M.S. (2000). Penggunaan Triokontanol dan Jarak Tanam pada Tanaman Kacang Hijau (Phaseolus radiatus L.). Agrosains, 2(2): 59-63.

Buntuang, S., Zakaria, F., dan Pembengo, W. (2014). Pengaruh Waktu Naungan Plastic Transparan dan Jumlah Tanaman Perlubang Tanam terhadap Pertumbuhan dan Hasil Tanaman Kacang Hijau (Vigna radiate L.). Jurnal Agroteknotropika, 3(3): 153-161. Chairudin, Efendi, dan Sabaruddin. (2015). Dampak Naungan terhadap Perubahan Karakter Agronomi dan Morfo-Fisiologi Daun pada Tanaman Kedelai (Glycine max (L.) Merrill). J. Floratek, 10: $26-35$.

Daeli, N.D.S., Putri, L.A.P., dan Nuriadi, I. (2013). Pengaruh Radiasi Simar Gamma terhadap Tanaman Kacang Hijau (Vigna radiata L.) pada Kondisi Salin. Jurnal Online Agroekoteknologi, 1(2): 227-237.

Deselina. (2014). Karakteristik Fisiologis dan Kualitas Semai Jabon (Anthocephalus cadamba Miq.) terhadap Pemberian Naungan dan Komposisi Media Semai. Jurnal Agriculture, 9(3): 1015-1023.

Haryanti, S., dan Budihastuti, R. (2015). Morfoanatomi, Berat Basah Kotiledon dan Ketebalan Daun Kecambah Kacang Hijau (Phaseolus vulgaris L.) pada Naungan yang Berbeda. Buletin Anatomi dan Fisiologi, 23(1): 4756.
Iqbal, M., Mawarni, L., dan Charloq. (2013). Pertumbuhan dan Produksi Beberapa Varietas Kedelai (Glycine max L. Merrill) pada Berbagai Tingkat Penaungan Tahap Kedua. Jurnal Online Agroekoteknologi, 1(3): 896-907.

Nasution, A.S. (2015). Pengaruh Pemberian Berbagai Jenis Pupuk Organik terhadap Pertumbuhan dan Produksi Tanaman Kacang Hijau (Vigna radiata L.). Agrium, 19(2): 8995.

Polnaya, F., dan Patty, J.E. (2012). Kajian Pertumbuhan dan Produksi Jagung Lokal dan Kacang Hijau dalam sistem Tumpang sari. Agrologia, 1(1): 42-50.

Reskynawati, K. (2014). Pertumbuhan dan Produksi Tanaman Kacang Hijau (Vigna radiate L.) pada Berbagai Tingkat Naungan. [Skripsi]. Prodi Agroteknologi, Jurusan Budidaya Pertanian, Fakultas Pertanian, Universitas Hassanudin. Makassar.

Sopandie,

D.,

dan

Trikoesoemaningtyas. (2011). Pengembangan Tanaman Sela di Bawah Tegakan Tanaman Tahunan. Iptek Tanaman Pangan, 6(2): 168-182.

Sucipto. (2009). Dampak Pengaturan Baris Tanaman Jagung (Zea mays L.) dan Populasi Kacang Hijau (Phaseolus radiates L.) dalam Tumpangsari terhadap Pertumbuhan dan Hasil Kacang Hijau, Jagung. Jurnal Agrovigor, 2(2): 67-78.

Sumarji. (2013). Laporan Kegiatan Penyuluhan Teknik Budidaya Kacang Hijau (Vigna radiata (L) 
Wilczek). Prodi Agroteknologi, Fakultas Pertanian, Universitas Islam Kediri.

Sundari, T., Soemartono, Tohari, dan Mangoendidjojo, W. (2005). Keragaan Hasil dan Toleransi Genotipe Kacang Hijau terhadap Penaungan. Jurnal IImu Pertanian, 12(1): 12-19.

Susanto, G.W.A., dan Sundari, T. (2011). Perubahan Karakter Agronomi Aksesi Plasma Nutfah Kedelai di Lingkungan Ternaungi. Jurnal Agron. Indonesia, 39(1): 1-6.

Syaiful, S.A, Yassi, A., dan Rezkiani, N. 2011). Respon Tumpangsari Tanaman Jagung Manis dan Kacang Hijau terhadap Sistem Olah Tanah dan Pemberian Pupuk Organik. J. Agronomika, 1(1): 13-18.

Taufiq, A., dan Sundai, T. (2012). Respons Tanaman Kedelai terhadap Lingkungan Tumbuh. Buletin Palawija, 23: 13-26.

Trustinah, B.S., Radjit, N., Prasetiaswati, dan Harnowo, D. (2014). Adopsi Varietas Unggul Kacang Hijau di Sentra Produksi. Iptek Tanaman Pangan, 9(1): 24-38.

Yugi, R.A., dan Harjoso, T. (2012). Karakter Hasil Biji Kacang Hijau pada Kondisi. 